\title{
Comparison of the Role of Endocan With Other Laboratory Tests in Diagnosis of Acute and Perforated Appendicitis in Children
}

\section{Endokanın Çocuklardaki Akut ve Perfore Apandisit Tanısındaki Rolünün Diğer Laboratuvar Testleri ile Kıyaslanması}

\author{
(D) Mehmet Nuri CEVIZCİ1 ${ }^{1}$, id Soner Sertan KARA², id Engin ŞEBIN³3, iD Mahmut ŞENYURT³ \\ 'Balıkesir University Faculty of Medicine, Department of Pediatric Surgery, Balıkesir, Turkey \\ 2Erzurum Regional Training and Research Hospital Clinic of of Pediatric Infectious Diseases, Erzurum, Turkey \\ ${ }^{3}$ Regional Training and Research Hospital Clinic of Biochemistry, Erzurum, Turkey
}

\begin{abstract}
Objective: In this study, we aimed to determine the role and efficacy of endocan and other routine laboratory tests to diagnose of acute appendicitis (AA) and determining perforation.

Methods: One hundred patients under the age of 16 who were diagnosed appendicitis were included the study. The patients were divided into two groups as acute and perforated appendicitis. Complete blood count, C-reactive protein (CRP) and endocan values were evaluated on admission and on postoperative $48^{\text {th }}$ hour. Obtained endocan samples and concomitantly obtained CRP, white blood cell (WBC) count, and neutrophil lymphocyte ratio (NLR) parameters were compared preoperatively and postoperatively in terms of perforated and non-perforated (acute) appendicitis.

Results: In this study, $74.2 \%$ of the patients were acute and $25.8 \%$ were perforated. In both groups, more than half of the patients had an endocan value of less than $50 \mathrm{ng} / \mathrm{mL}$. Specificity and sensitivity of endocan were lower than other inflammation markers to determine $\mathrm{AA}$ and perforation. It was shown that the combined evaluation of CRP and NLR values of $<9$ and $<15$ respectively, were the best data to diagnose AA and perforation.

Conclusion: The efficacy of endocan was significantly lower than the other routine laboratory markers to determine AA and perforation. It seems more beneficial to use CRP and NLR together to detect infection during early and late period.
\end{abstract}

Keywords: Endocan, child, appendicitis

\section{ÖZ}

Amaç: Bu çalışmada, endokan ve diğer rutin laboratuvar testlerinin akut apandisit (AA) tanısında ve perforasyonun belirlenmesindeki rolünü ve etkinliğini belirlemeyi amaçladık.

Yöntemler: Çalışmamıza 16 yaşından küçük, apandisit tanısı konmuş 100 hasta dahil edildi. Hastalar akut ve perfore apandisit olarak iki gruba ayrıldı. Tam kan sayımı, C-reaktif protein (CRP) ve endokan değerleri başvuru sırasında ve ameliyat sonrası 48 . saatte bakıldı. Elde edilen endokan örnekleri ve aynı zamanda alınan CRP, beyaz kan hücresi sayısı (WBC) ve nötrofil lenfosit oranı (NLR) parametreleri, preoperatif ve postoperatif olarak perfore ve perfore olmayan (akut) apandisit açısından karşılaştırıldı.

Bulgular: Bu çalışmada hastaların \%74,2'si akut, \%25,8'i perfore apandisit tanısı aldı. Her iki grupta da hastaların yarısından fazlasında endokan değeri $50 \mathrm{ng} / \mathrm{mL}$ 'den daha az olarak saptand. AA ve perforasyonu belirlemek için endokanın özgüllüğü ve duyarlılığı diğer inflamasyon belirteçlerinden daha düşük bulundu. CRP $<9$ ve NLR $<15$ olan olgularda birlikte değerlendirilmeleri AA tanısı ve perforasyonun ayırıcı tanısında en uygun belirteçler olduğu gösterildi.

Sonuç: Endokanın AA ve perforasyonu belirlemedeki etkinliği diğer rutin laboratuvar belirteçlerinden anlamlı derecede düşük bulundu. Erken ve geç dönemde enfeksiyonun saptanması için CRP ve NLR'nin birlikte kullanılması daha yararlı olduğu gösterildi.

Anahtar Sözcükler: Endokan, çocuk, apandisit

Address for Correspondence: Mehmet Nuri CEVizCi, Balıkesir University Faculty of Medicine, Department of Pediatric Surgery, Balıkesir, Turkey

Phone: +90 5059423272 E-mail: drcevizci77@yahoo.com ORCID ID: orcid.org/0000-0001-6214-5377

Cite this article as: Cevizci MN, Kara SS, Şebin E, Şenyurt M. Comparison of the Role of Endocan With Other Laboratory Tests in Diagnosis of Acute and Perforated Appendicitis in Children. Bezmialem Science 2020;8(2):175-81. 


\section{Introduction}

Appendicitis is one of the causes of abdominal pain in children that requires urgent surgery. Early diagnosis and treatment of this progressively inflammatory disease is very important. Delay in diagnosis and surgical intervention may lead to serious complications such as abscess mostly localised to subhepatic and retroperitoneum regions, ileus, bacteremia, sepsis, necrotizing fasciitis and appendico-vesical fistula which increase mortality and morbidity $(1,2)$. On the contrary, it is stated that early surgical interventions due to uncertain diagnosis increase the rate of negative appendectomy $(3,4)$. In children, it is difficult to diagnose acute appendicitis, hence they easily get agitated with physical examination and the history of the patient and symptoms are obtained indirectly. That's why, patients with acute appendicitis (AA) can often be confused with some conditions clinically (such as., familial mediterranean fever (FMF), invagination, gastroenteritis, pneumonia, urinary system infections, ovarian torsion and pelvic inflammatory disease) $(2,5,6)$. In addition to history, physical examination and radiological evaluation, the most commonly used laboratory tests to support AA diagnosis include white blood cell count (WBC), neutrophil lymphocyte ratio (NLR) and C-reactive protein (CRP). However, many markers that are known to have accuracy in inflammatory reactions (such as erythrocyte sedimentation rate, procalcitonin, interleukin 6,8, haptoglobin, granulocyte colony-stimulating factor, lactoferrin, calprotectin, mid platelet volume, plateletcrit) have been proposed to support the diagnosis (7). As in those laboratory tests, many recently developed clinical scoring systems have been found to be inadequate for AA diagnosis in routine practice (8-11).

Endocan is a proteoglycan released from the vascular endothelial surface. Its release is regulated by cytokines and growth factors such as vascular endothelial growth factor (12). Since endocan is mainly released from endothelium of lungs and kidneys, it is seen that studies in the literature largely focuse on these two systems (13-16). There are also many studies showing the importance of endocan in the diagnosis and prognosis of acute and chronic infections, as well as sepsis and septic shock (17-20). In some studies, endocan has been shown to increase earlier than some infectious markers such as CRP and procalcitonin at the onset of infection and decreased later than the others $(12,21)$. Endocan has also been shown to be elevated in FMF, which is often confused with AA, and those elevated levels have been shown to persist in non-exacerbated periods as well (20). In literature, we did not find any study in which endocan was used as a diagnostic marker in children with AA.

In this study, we evaluated the correlation of serum endocan levels detected in the early and late phase of an appendicitis together with some other inflammatory markers (such as,. WBC, NLR and CRP) and whether it could be helpful or not in distinguishing acute or perforated appendicitis.

\section{Methods}

Ethics approval: Erzurum Regional Education and Research Hospital Ethics Committee approved this study (20.05.2014 / 10-3).
Between March 2015 and May 2016, 100 patients under the age of 16 who were operated with the diagnosis of appendicitis were prospectively included in the study. Patients' parents were informed about the study during the admission. Written consents were obtained from the parents on the basis of volunteerism. The patients were divided into two groups as acute and perforated appendicitis. Appendicitis diagnosis was made with physical examination, history, laboratory tests (WBC, NLR, and CRP) and abdominal ultrasonography.

Antibiotic therapy with ampicillin-sulbactam $(150 \mathrm{mg} / \mathrm{kg} / \mathrm{day}$, divided into four equal doses) was initiated in all patients with AA pre-diagnosis prior to surgery. Metranidazole $(30 \mathrm{mg} / \mathrm{kg} / \mathrm{day}$, divided into three equal doses) and amikacin $(15 \mathrm{mg} / \mathrm{kg} / \mathrm{day}$, divided into two equal doses) were added to the patient's initial terapy who were presented with perforation during surgery. The distinction between the presence or absence of perforation in the patients who underwent surgery was made with intraoperative evaluation and the afterwards histopathological examination. Patients who were diagnosed with additional clinical presentations other than appendicitis such as invagination, Meckel diverticulum, over torsion, mesenteric lymphadenitis and primary peritonitis were excluded. Three patients who were diagnosed as having appendicitis were excluded from the study, due to personal excuses. Patients who agreed to participate in the study were tested for complete blood counts and CRP at the admission and at 48 hours after the surgery. In addition, blood samples were taken to another hemogram tube simultaneously to measure endocan level. Samples were centrifuged at 4000 $\mathrm{rpm}$ for $10 \mathrm{~min}$ at $+4{ }^{\circ} \mathrm{C}$. Serum samples were aliquoted and transferred to eppendorf tubes and placed in the deep freezer at $-80^{\circ} \mathrm{C}$ and held there till the day they were analyzed. Endocan levels in the serum samples were measured in the direction of the manufacturer's firm using the "Human Endocan / esm-1 ELISA Kit” (SuNLRng Biotech Co., Ltd., Lot No.: SL2210Hu, China) via Enzyme-Linked Immunosorbent Assay (ELISA) method. The analysis was performed with BioTek Power Wave ST microplate spectrophotometer (USA). Concomitant CRP, complete WBC, and NLR parameters were compared simultaneously with the endocan levels preoperatively and postoperatively in both patients with acute and perforated appendicitis.

\section{Statistical Analyses}

Data were analyzed with Minitab Statistical package (PA, USA) and checked for distribution by using Anderson-Darling formula. As none of the parameters had normal distribution, they were converted into $\log 10$ scale. Following this conversion, LNR values had normal distribution but the other data, except a slight improvement, did not distribute normally. Therefore, nonparametric Kruskal-Wallis test was used to analyze the data in terms of age, sex, diagnosis (acute and perforated appendicitis) and time (pre- and post-operative). An additional attempt was made to test whether there were any interactions between the parameters studied. For that purpose, generalized linear model (GLM) was used to find out the effects of each parameter and their interactions. GLM procedure resulted in similar levels of significance for each parameter. Furthermore, there were no interactions between any of the parameters . Correlation analyses were carried out by using Spearman rho. The data 
were presented as mean \pm SEM and $\mathrm{p} \leq 0.050$ was denoted as statistically significant. Although analyses were carried out with $\log 10$ converted values, results were presented as original values.

\section{Results}

Of the 97 patients in sum, 72 patients (74.2\%) had acute and 25 patients $(25.8 \%)$ had perforated appendicitis. There was no difference between the groups in terms of age. The number of males was higher in both groups, and male gender was more pronounced in the perforated appendicitis group (Table 1).

WBC did not change by age $(\mathrm{p}=0.415)$ but males had higher WBC values than the females $(\mathrm{p}=0.002)$. Additionally, WBC values were higher in perforated appendicitis than acute appendicitis $(p<0.001)$ and were higher in pre-op period than post-op period $(\mathrm{p}<0.001)$. If $\mathrm{WBC}$ counts $>6.25$ were used to
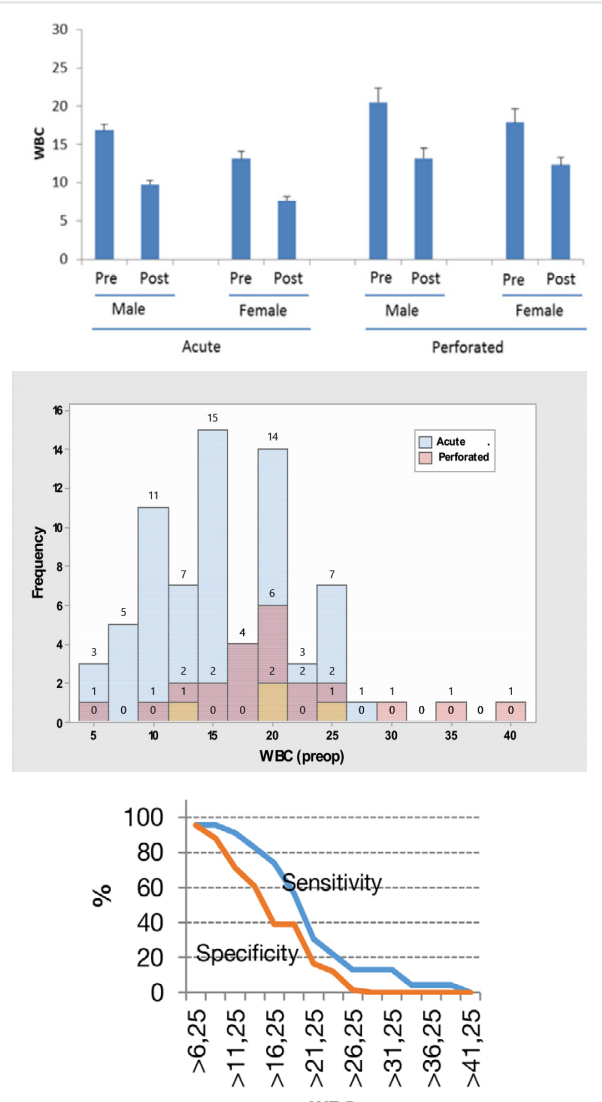

WBC

Figure 1. WBC values and WBC's specificity and sensitivity WBC: White blood cell count describe (or diagnose) perforated appendicitis, both specifity and sensitivity were between $90-100 \%$. However, as new WBC count criteria $(>5,>7$ etc.) were applied, both the sensitivity and specificity decreased (Figure 1).

CRP did not change by age $(\mathrm{p}=0.193)$ or by sex $(\mathrm{P}=0.426)$. However CRP values were higher in perforated appendicitis than acute appendicitis $(\mathrm{P}<0.001)$ and were higher in post-op period than pre-op period $(\mathrm{p}<0.001)$. If CRP levels $>1$ were used to describe (or diagnose) perforated appendicitis, specificity was between $40-50 \%$ and sensitivity was between $90-100 \%$. However, as specificity increased by new CRP criteria $(>3,>5$ etc), sensitivity decreased. The graph also shows that both the sensitivitiy and specificity are between $60-100 \%$ if CRP criteria $>9$ are used (Figure 2).
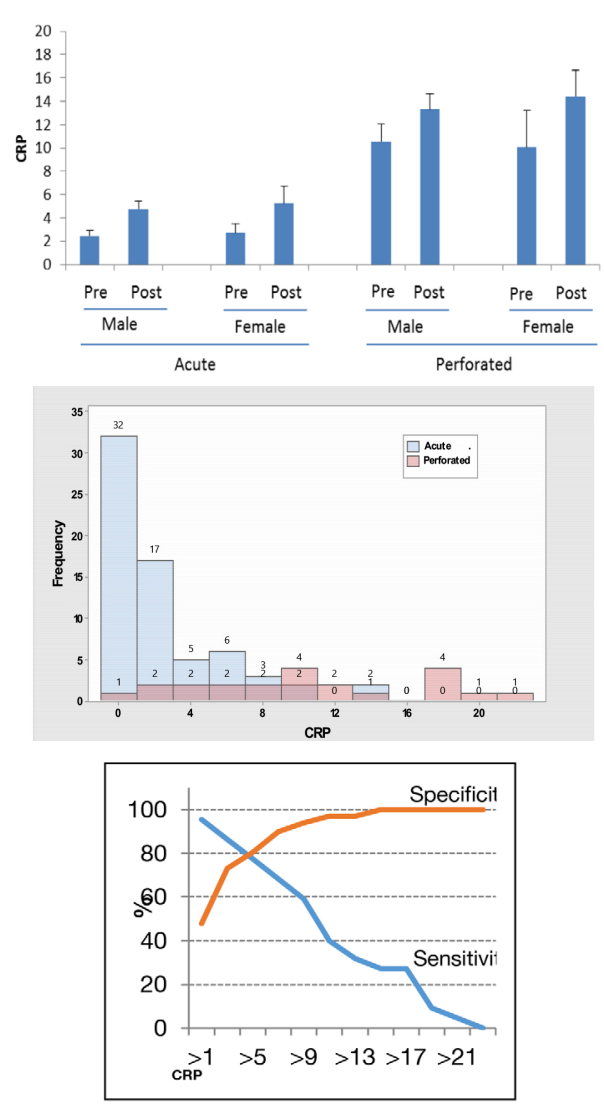

Figure 2. CRP values and CRP's specificity and sensitivity CRP: C-reaktive protein

Table 1. Age and gender distribution of patients

\begin{tabular}{|c|c|c|c|c|c|c|}
\hline & $\begin{array}{l}\text { Non-perforated } \\
\text { preoperative } \\
\text { n (72) }\end{array}$ & $\begin{array}{l}\text { Non-perforated } \\
\text { postoperative } \\
\mathrm{n}(72)\end{array}$ & $\mathrm{P}$ & $\begin{array}{l}\text { Perforated } \\
\text { preoperative } \\
\text { n (25) }\end{array}$ & $\begin{array}{l}\text { Perforated } \\
\text { postoperative } \\
\mathrm{n}(25)\end{array}$ & $\mathrm{p}$ \\
\hline Age (years) & $10.7 \pm 2.9$ & $10.7 \pm 2.9$ & & $9.2 \pm 37$ & $9.2 \pm 37$ & 0.62 \\
\hline Male/female & $49 / 23$ & $49 / 23$ & & $20 / 5$ & $20 / 5$ & \\
\hline male (\%) & 68.1 & 68.1 & 0.002 & 80 & 80 & 0.003 \\
\hline female (\%) & 31.9 & 31.9 & & 20 & 20 & \\
\hline
\end{tabular}


NLR did not change by age $\mathrm{p}=0.247)$ and by sex $(\mathrm{p}=0.173)$. However, NLR values were higher in perforated appendicitis than acute appendicitis $(\mathrm{p}<0.001)$ and were higher in pre-op period than post-op period $(\mathrm{p}<0.001)$. If $\mathrm{N} / \mathrm{L}$ ratios $>3$ were used to describe (or diagnose) perforated appendicitis, specificity was around $10 \%$ and sensitivity was $100 \%$. However, as specificity increased by new N/L ratio criteria $(>5,>7$ etc), sensitivity decreased (Figure 3).

Correlation of pre-op CRP and N/L ratio in relation to diagonsis (acute versus perforated appendicitis) can be seen from the graphic 1. CRP levels $<9$ and N/L ratio $<15$ described the most of the data as being acute. According to this criteria, sensitivity was $80 \%$ and specificity was $95.7 \%$ (Graphic 1).

Endocan values changed by age $(\mathrm{p}<0.001)$, being the highest in the age groups of 2,5 and 16 years than the other age groups ( 4 , $7,8,9,10,11,12,13,14,15)$. Additionally, males had higher endocan levels than females $(\mathrm{p}=0.018)$. However, endocan values did not differ between perforated and acute appendicitis groups $(\mathrm{p}=0.979)$ and between pre-op and post-op periods $(\mathrm{p}=0.281)$. If endocan levels $>50$ were used to describe (or diagnose) perforated appendicitis, both specificity and sensitivity were between $40-$ $60 \%$. However, as specificity increased by new endocan criteria $(>150,>250$ etc), sensitivity decreased to zero (Figure 4). Preop and pos-top endocan levels were positively and significantly correlated (R-sq=0.636 and $\mathrm{p}<0.001)$ (Graphic 2).
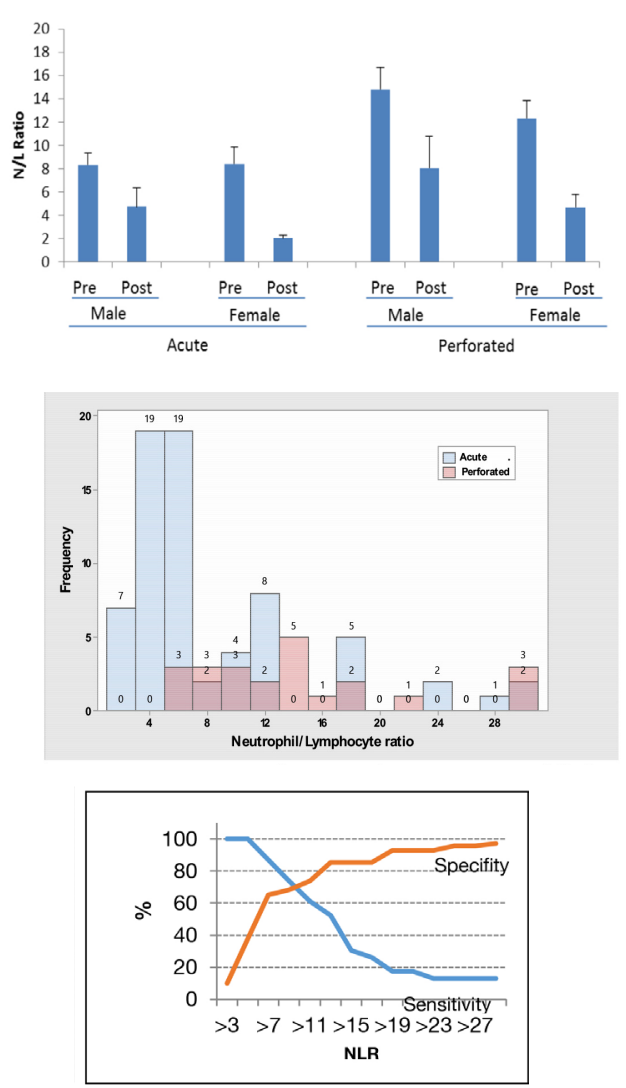

Figure 3. NLR values and NLR's specificity and sensitivity NLR: Neutrophil lymphocyte ratio
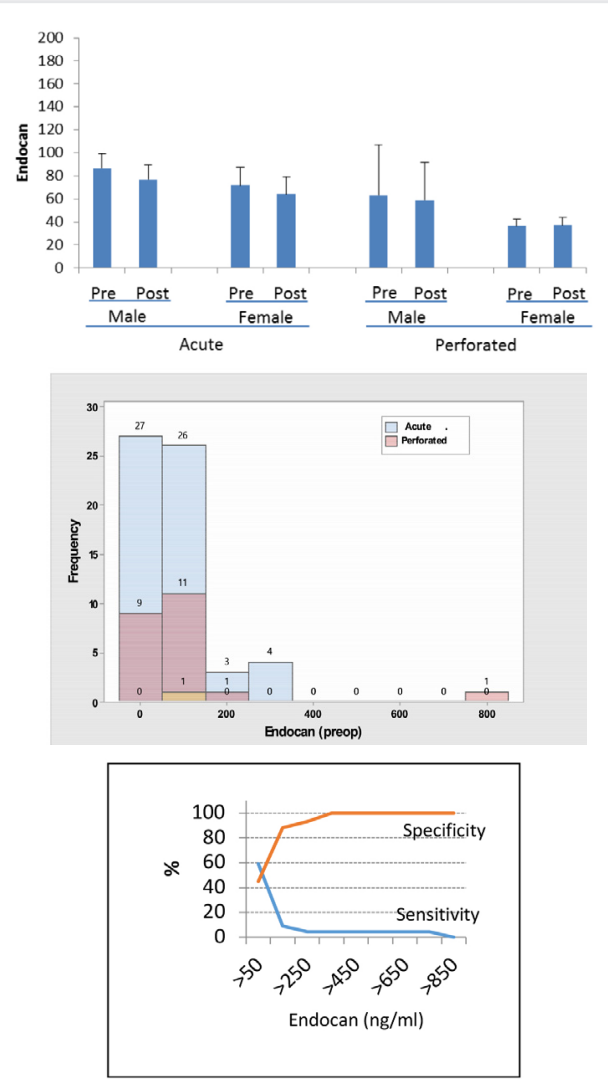

Figure 4. Endocan values and endocan's specificity and sensitivity

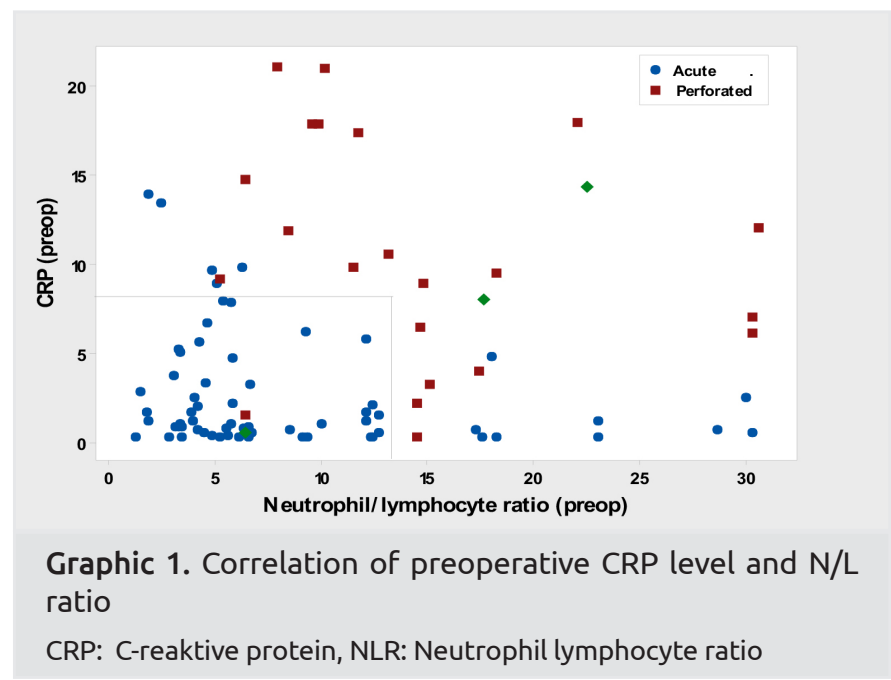

\section{Discussion}

Appendicitis is one of the causes of abdominal pain in which urgent surgery is needed inchildren. However, distinguishing this situation from other causes of abdominal pain is particularly difficult in young children and the perforation rate increases with younger age.

For this reason, early diagnosis and treatment of the disease is very important. In this study, endocan levels were higher in male 


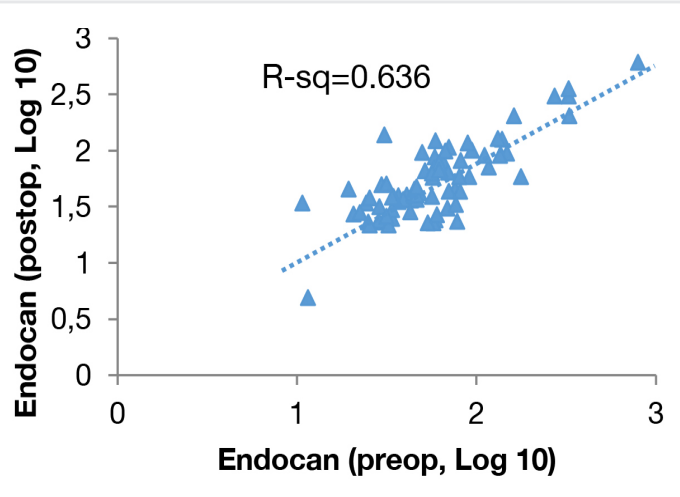

Graphic 2. Correlation of preoperative and postoperative endocan levels

patients than in females, the highest levels were obtained in the ages of 2.5 and 16 years and varied significantly with age. We could not find any meaningful reason to explain the difference in age and gender. When the preoperative endocan values over $50 \mathrm{ng} / \mathrm{mL}$ were taken as basis, the specificity and sensitivity on diagnosis of perforated appendicitis were found between 40$60 \%$. When these base values were taken higher than $150 \mathrm{ng} /$ $\mathrm{mL}$, the specificity was significantly increased and the sensitivity was decreased. However, the mean preoperative endocan values in our study were $52.3 \mathrm{ng} / \mathrm{mL}$ in the perforated appendicitis group and $52.9 \mathrm{ng} / \mathrm{mL}$ in the acute appendicitis group. In both groups more than half of the patients had an endocan value of less than $50 \mathrm{ng} / \mathrm{mL}$. Based on this value, both the sensitivity and specificity of endocan were lower in the diagnosis of perforated appendicitis compared to the other classical markers. In addition, there was no statistically significant difference between the preoperative and postoperative endocan values and it was noticed that there was a significant positive correlation between the two values. Endocan has been shown to be a useful marker for monitoring prognosis and the efficacy of the treatment in serious infections requiring long-term therapy exceeding more than one week (12,17-19). However, in our study, because of the similarity of the serum endocan values detected at $48^{\text {th }}$ hour with the preoperative values, it could be said that endocan was not as effective as other laboratory markers in diagnosing diseases requiring short-term treatment such as appendicitis and demonstrating the treatments efficacy.

When we looked at the accuracy of the markers in diagnosis of $\mathrm{AA}$ and detecting perforation; we saw that WBC increased in $70 \%$ of the reasons that caused pain in the right lower quadrant, for this reason diagnostic value of WBC was low. Instead of WBC, NLR was reported as more valuable in the diagnosis and a significant inflammatory index for appendicitis, which was above $85 \%(20,22)$. In our study, in acute and perforated appendicitis, preoperative WBC and NLR values were significantly higher than postoperative values. It was shown that $\mathrm{WBC}$ was more sensitive (sensitivity was above $80 \%$ ) in showing perforated appendicitis between the values of $10-16 \times 10^{3}$ and the specificity was around $60 \%$. At higher WBC values, both specificity and sensitivity were significantly decreased. Therefore, it could be said that the values of $16 \times 10^{3}$ and below were more reliable when the WBC value was used to detect perforated appendicitis, and the probability of a wrong diagnosis increased when values above $16 \times 10^{3}$ were considered. When we looked at the neutrophil and lymphocyte distribution ratio, it was observed that NLR was higher in males and this ratio did not change with age. In addition, preoperative values were higher in both groups, which were more prominent in perforated appendicitis. The lower values of NLR were found to be more valuable in determining the perforation. The specificity was low (10-60\%) and the sensitivity was high $(>80 \%)$ in the values where the rate was low (range 3-7). At the intersection point where both sensitivity and specificity were $70 \%$; NLR value was 9. Sensitivity was found to decrease significantly in the values where the ratio was higher, but specificity was found to increase.

In the inflammatory events, CRP starts to be synthesized 4-6 hours after tissue damage begins, but reaches its peak value after 36-50 hours. Therefore, CRP is more sensitive in the late period of appendicitis. In other words, it is known that the sensitivity of CRP in the first 12 hours is relatively low in case of perforation or abscess. In their study, Xharra et al. showed that the diagnostic value of CRP was not superior to that of WBC and NLR, more likely it indicated the severity of AA and the elapsed time (19). In many studies it has been shown that the combined use of these three markers (WBC, LNO, and CRP) is more reliable in determining $\mathrm{AA}$ and perforation (23-25). CRP values at the $48^{\text {th }}$ hour after operation were significantly higher in both groups in our study. According to these results were considered, AA diagnosis could not be excluded when CRP levels in the first 24 hours and WBC and NLR levels after 48 hours were low. In their study, Kharbanda et al. found that children with acute appendicitis who were followed up with abdominal pain less then 24 hours were found to have a higher serum WBC value, children who had a 24-48-hour pain were found to have higher CRP values (26). Considering this result, it can be said that these markers are more sensitive in showing the duration of symptoms since the onset, rather than deciding whether the situation is acute or perforated. So that, whether it is acute or perforated, the results obtained within the first 24 hours or after that may differ independently from the patients' clinical situation. Our laboratory results were similar with this study. Although there were no trustworthy data on how long ago the patients' symptoms began at the time of admission, the higher values of WBC and NLR in the first samples and the higher CRP in the $48^{\text {th }}$ hour samples supported the relationship of those markers with time independently from the patients' clinic situation. When we evaluated the correlation of CRP levels with perforated appendicitis in the perforation group, CRP was found to be significantly higher. When these markers were used alone, the sensitivity and specificity were usually reversed, while one was increasing, the other decreased. Therefore, it appears to be more useful to use these markers in combination to determine appendicitis and perforation. In our study, CRP $<9$ and NLR $<15$ in the pre-op period were found to be the best predictors to show AA. In the diagnosis of perforated appendicitis; sensitivity and specificity were found to be $80 \%$ and $95.7 \%$, respectively. 


\section{Study Limitations}

Our study had its own limitations. Limited assessment of endocan at 48 hours as an inflammatory marker appeared to be the most important restriction of this study. For this reason, we thought that the patient group with appendicitis was not very suitable for studying this marker. In addition, the fact that the time between the onset of symptoms and the presence of AA was not objectively determined, led to limitations in assessing the effectiveness of markers in diagnosis of AA and perforation.

\section{Conclusion}

As a result, endocan, which was known to be an important marker in diagnosis and prognosis of diseases presenting with chronic inflammation and some infections was not shown to be effective in distinguishing acute and perforated appendicitis. Combined evaluation of 2 of the routine laboratory tests and their defined cut-off values, CRP $<9$ and NLR $<15$, were found to be the best for diagnosis of AA and determination of perforation. We think it would be more helpful to use the combination of routine laboratory tests to enhance clinical and radiological assessment which can reduce unnecessary surgery and delays on diagnosis with the error margin.

\section{Ethics}

Ethics Committee Approval: Erzurum Regional Education and Research Hospital Ethics Committee approved this study (20.05.2014/ 10-3).

Informed Consent: Written consents were obtained from the parents on the basis of volunteerism.

Peer-review: Externally peer reviewed.

\section{Authorship Contributions}

Surgical and Medical Practices: M.N.C., Data Collection or Processing: E.Ş., M.Ş., Analysis or Interpretation: S.S.K., Literature Search: M.N.C., Writing: M.N.C.

Conflict of Interest: No conflict of interest was declared by the authors.

Financial Disclosure: No funding was received.

This study was presented as an oral presentation in the $36^{\text {th }}$ National Children's Surgery Congress and $3^{\text {th }}$ International Pediatric Endoscopic Surgery Group - Middle East Participation Congress, 24-27 October 2018, Izmir/ Turkey.

Acknowledgment: All procedures performed in studies involving human participants were in accordance with the ethical standards of the institutional and/or national research committee and with the 1964 Helsinki Declaration and its later amendments or comparable ethical standards.

\section{References}

1. Kim JS. Acute abdominal pain in children. Pediatr Gastroenterol Hepatol Nutr 2013;16:219-224.
2. Huckins DS, Simon HK, Copeland K, Spiro DM, Gogain J, Wandell M. A novel biomarker panel to rule out acute appendicitis in pediatric patients with abdominal pain. Am J Emerg Med 2013;9:1368-75.

3. Benito J, Acedo Y, Medrano L, Barcena E, Garay RP, Arri EA. Usefulness of new and traditional serum biomarkers in children with suspected appendicitis. Am J Emerg Med 2016;34:871-6.

4. Garcia peña BM, Cook EF, Mandl KD. Selective imaging strategies for the diagnosis of appendicitis in children. Pediatrics 2004;113:248.

5. Trout AT, Sanchez R, Ladino-Torres MF, Pai DR, Strouse PJ. A critical evaluation of US for the diagnosis of pediatric acute appendicitis in a real-life setting: how can we improve the diagnostic value of sonography? Pediatr Radiol 2012;42:813-23.

6. Buyukbese SS, Sarac F. Diagnostic value of white blood cell and C-reactive protein in pediatric appendicitis. Biomed Res Int. 2016 May 4.

7. Allister L, Bachur R, Glickman J, Horwitz B. Serum markers in acute appendicitis. J Surg Res 2011;168:70-5.

8. Mandeville K, Pottker T, Bulloch B, Liu J. Using appendicitis scores in the pediatric ED. Am J Emerg Med 2011;29:972-7.

9. Samuel M. Pediatric appendicitis score. J Pediatr Surg 2002;37:87781.

10. Macco S, Vrouenraets BC, DE Castro SM. Evaluation of scoring systems in predicting acute appendicitis in children. Surgery 2016;160:1599-604.

11. Peyvasteh M, Askarpour S, Javaherizadeh H, Besharati S. Modified alvarado score in children with diagnosis of appendicitis. Arq Bras Cir Dig 2017;30:51-2.

12. Seo K, Kitazawa T, Yoshino Y, Koga I, Ota Y. Characteristics of serum endocan levels in infection. PLoS One 2015;10:e0123358.

13. Kim JH, Park MY, Kim CN, Kim KH, Kang HB, Kim KD, et al. Expression of endothelial cell-specific molecule-1 regulated by hypoxia inducible factor- $1 \alpha$ in human colon carcinoma: impact of ESM-1 on prognosis and its correlation with clinicopathological features. Oncol Rep 2012;28:1701-8.

14. Leroy X, Aubert S, Zini L, Franquet H, Kervoaze G, Villers A, et al. Vascular endocan (ESM-1) is markedly overexpressed in clear cell renal cell carcinoma. Histopathology 2010;56:180-7.

15. Kupeli I, Salcan S, Kuzucu M, Kuyrukluyıldız U. Can endocan be a new biomarker in ventilator-associated pneumonia? Kaohsiung J Med Sci 2018;34:689-94.

16. Kiral E, Dinleyici EC, Bozkurt-Turhan A, Bor O, Akgun Y, Akgun NA. Serum endocan levels in children with febrile neutropenia. Hematol Rep 2016;8.

17. Scherpereel A, Depontieu F, Grigoriu B, Cavestri B, Tsicopoulos A, Gentina T, et al. Endocan, a new endothelial marker in human sepsis. Crit Care Med 2006;34:532-7.

18. Pauly D, Hamed S, Behnes M, Lepiorz D, Lang S, Akin I, et al. Endothelial cell-specific molecule-1/endocan: Diagnostic and prognostic value in patients suffering from severe sepsis and septic shock. J Crit Care 2016;31:68-75. 
19. Xharra S, Gashi-Luci L, Xharra K, Veselaj F, Bicaj B, Sada F, et al. Correlation of serum C-reactive protein, white blood count and neutrophil percentage with histopathology findings in acute appendicitis. World J Emerg Surg 2012;7:27.

20. Ozalper V, Kara M, Tanoglu A, Cetındaglı I, Ozturker C, Hancerlı $\mathrm{Y}$, et al. Evaluation of endothelial dysfunction in patients with familial Mediterranean fever: the relationship between the levels of asymmetric dimethylarginine and endocan with carotid intimamedia thickness and endothelium-dependent vasodilation. Clin Rheumatol 2017;36:2071-7.

21. Andersson RE, Hugander AP, Ghazi SH, Ravn H, Offenbartl SK, Nyström PO, et al. Diagnostic value of disease history, clinical presentation, and inflammatory parameters of appendicitis. World J Surg 1999;23:133-40.

22. Keskek M, Tez M, Yoldas O, Acar A, Akgul O, Gocmen E, et al. Receiver operating characteristic analysis of leukocyte counts in operations for suspected appendicitis. Am J Emerg Med 2008;26:769-72.
23. Yu CW, Juan LI, Wu MH, Shen CJ, Wu JY, Lee CC. Systematic review and meta-analysis of the diagnostic accuracy of procalcitonin, C-reactive protein and white blood cell count for suspected acute appendicitis. Br J Surg 2013;100:322-9.

24. Daly MC, Von Allmen D, Wong HR. Biomarkers to estimate the probability of complicated appendicitis. J Pediatr Surg 2018;53:43740.

25. Atema JJ, Gans SL, Beenen LF, Toorenvliet BR, Laurell H, Stoker $\mathrm{J}$, et al. Accuracy of white blood cell count and C-reactive protein levels related to duration of symptoms in patients suspected of acute appendicitis. Acad Emerg Med 2015;22:1015-24.

26. Kharbanda AB, Cosme Y, Liu K, Spitalnik SL, Dayan PS. Discriminative accuracy of novel and traditional biomarkers in children with suspected appendicitis adjusted for duration of abdominal pain. Acad Emerg Med 2011;18:567-74. 